\title{
Genetic progress in the UNB-2U population of popcorn under recurrent selection in Rio de Janeiro, Brazil
}

\author{
R.M. Ribeiro, A.T. do Amaral Júnior, L.S.A. Gonçalves, L.S. Candido, \\ T.R.C. Silva and G.F. Pena \\ Universidade Estadual do Norte Fluminense Darcy Ribeiro, \\ Campos dos Goytacazes, RJ, Brasil \\ Corresponding author: A.T. do Amaral Júnior \\ E-mail: amaraljr@uenf.br
}

Genet. Mol. Res. 11 (2): 1417-1423 (2012)

Received July 20, 2011

Accepted January 20, 2012

Published May 15, 2012

DOI http://dx.doi.org/10.4238/2012.May.15.12

\begin{abstract}
As part of the Universidade Estadual do Norte Fluminense recurrent selection program of popcorn, we evaluated full-sib families of the sixth cycle of recurrent selection and estimated genetic progress for grain yield and expansion capacity. We assessed 200 full-sib families for 10 agronomic traits, in a randomized block design, with two replications within sets in two environments: Campos dos Goytacazes and Itaocara, in the State of Rio de Janeiro, Brazil. There were significant differences for families/“sets" for all traits, indicating genetic variability that could be exploited in future cycles. In the selection of superior progenies, the Mulamba and Mock index gave the best gains for popping expansion (PE) and grain yield (GY), with values of 10.97 and $15.30 \%$, respectively, using random economic weights. By comparing the evolution of the means obtained for PE and GY in the cycles $\mathrm{C}_{0}, \mathrm{C}_{1}, \mathrm{C}_{2}, \mathrm{C}_{3}, \mathrm{C}_{4}, \mathrm{C}_{5}$, and predicted for $\mathrm{C}_{6}$, a steady increase was observed for both $\mathrm{PE}$ and $\mathrm{GY}$, with the addition of $1.71 \mathrm{~mL} / \mathrm{g}\left(\mathrm{R}^{2}=0.93\right)$ and $192.87 \mathrm{~kg} / \mathrm{ha}\left(\mathrm{R}^{2}=0.88\right)$, respectively, in each cycle. Given the good performance of this popcorn population in successive cycles of intrapopulation recurrent selection,
\end{abstract}


we expect that a productive variety with high expansion capacity will soon be available for producers in the north and northwest regions of Rio de Janeiro State, Brazil.

Key words: Zea mays; Selection index; Genetic gains; Full-sibling families

\section{INTRODUCTION}

In Brazil, the consumption of popcorn has increased over the years and has become an attractive economic activity for farmers throughout the country (Freitas Júnior et al., 2009a; Mendes de Paula et al., 2010; Moterle et al., 2011). However, the reduced number of cultivars available in the market is considered the main obstacle for this crop (Miranda et al., 2003; Simon et al., 2004; Aguiar et al., 2008; Freitas Júnior et al., 2009a; Silva et al., 2010; Rangel et al., 2011). According to Embrapa Maize and Sorghum, 498 cultivars of maize were made available for marketing in the 2010/2011 harvest, with only five varieties of popcorn (Zélia, IAC 112, IAC 125, RS 20 and UFVM2-Barão-Viçosa) (Cruz et al., 2011).

In this scenario, public institutions such as the Brazilian Agricultural Research Corporation (Empresa Brasileira de Pesquisa Agropecuária - EMBRAPA), Campinas Agronomic Institute (Instituto Agronômico de Campinas - IAC), State University of Maringá (Universidade Estadual de Maringá - UEM), Federal University of Viçosa (Universidade Federal de Viçosa - UFV) and Universidade Estadual do Norte Fluminense Darcy Ribeiro (UENF) have conducted several lines of research aimed at developing new varieties of popcorn with favorable agronomic traits and high popping expansion.

UENF has been operating since 1998, developing two research works: the use of recurrent selection in the UNB-2U population in order to obtain improved varieties (Pereira and Amaral, 2001; Daros et al., 2004; Santos et al., 2007; Freitas Júnior et al., 2009a; Amaral Júnior et al., 2010; Rangel et al., 2011) and the implementation of diallels to identify superior hybrids and parents for the formation of compounds (Freitas Júnior et al., 2006; Rangel et al., 2008; Silva et al., 2010, 2011).

The use of recurrent selection in the UENF breeding program has achieved satisfactory results, as verified by Freitas Júnior et al. (2009a), who found an increase in each cycle of $2.01 \mathrm{~mL} / \mathrm{g}\left(\mathrm{R}^{2}=0.96\right)$ and $264.08 \mathrm{~kg} / \mathrm{ha}\left(\mathrm{R}^{2}=0.89\right)$ for expansion capacity and grain yield, respectively, between the $\mathrm{C}_{0}$ and $\mathrm{C}_{4}$ cycles. Therefore, this study aimed to continue the UENF recurrent selection program, assess full-sib families of the sixth selection cycle and estimate the genetic progress for grain yield and expansion capacity.

\section{MATERIAL AND METHODS}

The recurrent selection method was used to achieve 200 full-sib families. The progeny were evaluated in two environments: Campos dos Goytacazes and Itaocara, Rio de Janeiro, Brazil. The varieties BRS Angela and RS-20 were used as controls in each trial, as well as the previous cycles (UNB 2U-C0, UNB 2U-C1, UNB 2U-C2, UNB 2U-C3, UNB 2U-C4, and UNB 2U-C5).

A randomized block design was used, with two replications in "sets". The 200 families and eight controls were arranged into eight sets. Thus, each set contained 25 families and eight controls, totaling 33 treatments. The experimental plots consisted of $5.00 \mathrm{~m}$ long single rows, spaced $0.90 \mathrm{~m}$ between the rows and $0.20 \mathrm{~m}$ between plants, totaling $55,555 \mathrm{pl} / \mathrm{ha}$. Three 
seeds were sown in each hole at a depth of $0.05 \mathrm{~m}$. Thinning was carried out 21 days after emergence, and one plant was left per hole.

According to soil analysis, sowing fertilization was performed by applying $800 \mathrm{~kg} / \mathrm{ha}$ of NPK fertilizer using the 04-14-08 formulation. The first top dressing was carried out 30 days after sowing by applying $300 \mathrm{~kg} / \mathrm{ha}$ of the $20-00-20$ formulation. The second fertilization was performed 45 days after sowing at a dosage of $260 \mathrm{~kg} / \mathrm{ha}$ of ammonium sulfate (Sawazaki, 2001).

The following traits were evaluated: average plant height $(\mathrm{PH})$, in $\mathrm{cm}$; average height of the insertion of the first ear (PHE), in cm; the average number of plants per plot (NP); average number of broken plants (NBP); average number of ears (NE); average number of sick ears (NSE); mean weight of ears (WE), in kg/ha; mean weight of 100 grains (W100), in grams; grain yield (GY), $\mathrm{kg} / \mathrm{ha}$, and popping expansion (PE), in $\mathrm{mL} / \mathrm{g}$.

The data of the traits were used for the analysis of variance, according to the statistical model $Y_{i j k l}=\mu+E_{i}+S_{j}+E_{i j}+R / E S_{i j k}+F / S_{j 1}+E F / S_{i j l}+\xi_{i j k l}$, in which: $Y_{i j k l}$ is the average phenotypic value of the plot; $\mu$ is the average; $E_{i}$ is the fixed effect of the $\mathrm{i}$-th environment; $\mathrm{S}_{j}$ is the effect of the j-th "set"; $\mathrm{ES}_{\mathrm{ij}}$ is the effect of the interaction between environments and sets; $\mathrm{R} / \mathrm{ES}_{\mathrm{ijk}}$ is the effect of the k-th replication within the interaction between the i-th environment and the $\mathrm{j}$-th set; $\mathrm{F} / \mathrm{S}_{\mathrm{j} 1}$ is the random effect of the $\mathrm{i}$-th genotype within the $\mathrm{j}$-th set; $\mathrm{EF} / \mathrm{S}_{\mathrm{ijl}}$ is the effect of the interaction between environments and genotypes within the $\mathrm{j}$-th set, and $\xi_{\mathrm{ijkl}}$ is the experimental error. The estimates of the components of variance were achieved and the estimator of the genotypic variance among families is expressed by: $\hat{\sigma}_{G}^{2}=\frac{M S F / S-M S R}{r r}$, in which: MSF/S: mean square of families within sets; MSR: mean square of the residue; r: replication, and e: environment. The phenotypic variance was expressed by the following equation: $\hat{\sigma}_{p}^{2}=\frac{M S F / s}{e r}$. The residual variance was expressed by: $\hat{\sigma}_{r}^{2}=\frac{M S R}{e r}$. The variance of the genotype versus environment interaction was determined by the equation: $\hat{\sigma}_{G E}^{2}=\frac{\frac{M S E F-F}{S}-M S R}{r} \frac{e-1}{\varepsilon}$, in which MS(E*F)/S: mean square of the families versus environment interaction within sets. Heritability based on the average of families was

estimated by the expression: $\hat{h}_{R}^{2}=\frac{\partial \hat{\theta}}{\partial \hat{p}}=\frac{\frac{M S F}{S}-M S R}{\frac{M S F}{S}}$. The percent genetic variation coefficient $\left(\mathrm{CV}_{\mathrm{g}}\right)$ was determined by: $c V_{g}=100 \sqrt{\frac{\sigma_{g}^{2}}{M S R}}$, and the index of variation, by: $I_{v}=\frac{v c_{g}}{c V_{g}}$. The predictions of gains by selection were obtained by the Mulamba and Mock index (1978).

\section{RESULTS AND DISCUSSION}

In the analysis of variance, significant differences were not observed by the $\mathrm{F}$ test at $5 \%$ probability only for the traits NSE and PE in relation to the source of environmental variation (Table 1). For the other characteristics, the significance demonstrates that the environments were distinct enough to promote differences between the traits evaluated. For the source of variation "set", the mean squares were significant $(\mathrm{P} \leq 0.05)$ for all traits, except for $\mathrm{PH}$. According to Rangel et al. (2011), the significance for the other characteristics strongly indicates the necessity and importance of using the randomized block design with arrangement of treatments in sets, since the absence of this source of variation could produce variations that result in loss of accuracy in the experiments.

Regarding the source of variation families within set $(\mathrm{F} / \mathrm{S})$, all traits revealed significance for this source of variation, which proves that there is sufficient genetic variability to be exploited in the selection of families in this cycle and in the next ones. For the source of variation environment versus families within set, significance was demonstrated for PE, PH and NSE, which indicates that the families behaved differently in relation to soil and climatic changes (Table 1). 


\begin{tabular}{|c|c|c|c|c|c|c|c|c|c|c|c|}
\hline \multirow[t]{2}{*}{ Source of variation } & \multirow[t]{2}{*}{ d.f. } & \multicolumn{10}{|c|}{ Mean squares } \\
\hline & & NP & NBP & PH & PHE & NE & NSE & WE & GY & W100 & PE \\
\hline Environment (E) & 1 & $2184.61^{* *}$ & $105.53^{\circ *}$ & $380206.45^{* *}$ & $142597.87^{* *}$ & $1335.01^{* *}$ & $0.43^{\mathrm{ns}}$ & $471589.25^{*}$ & $14452101.40^{\circ}$ & $36.14^{* *}$ & $15.41^{\mathrm{ns}}$ \\
\hline Sets (S) & 7 & $14.28^{* *}$ & $2.61^{\circ *}$ & $294.94^{\mathrm{ns}}$ & $730.47^{* *}$ & $116.96^{* *}$ & $0.85^{*}$ & $505105.62^{* *}$ & $1622606.10^{\circ *}$ & $9.05^{* *}$ & $51.16^{* *}$ \\
\hline $\mathrm{E} \times \mathrm{S}$ & 7 & $5.28^{\text {ns }}$ & $1.69^{\circ *}$ & $3084.07^{* *}$ & $1259.73^{* *}$ & $195.39^{* *}$ & $0.91^{*}$ & $1182300.45^{* *}$ & $2853361.40^{* *}$ & $5.98^{* *}$ & $16.98^{\circ}$ \\
\hline Repl. (R)/E x S & 16 & $17.98^{* *}$ & $2.56^{\circ *}$ & $2360.96^{* *}$ & $735.92^{* *}$ & $183.10^{* *}$ & $1.36^{* *}$ & $1365034.86^{* \circ}$ & $1945743.10^{\circ *}$ & $3.62^{* *}$ & $9.99^{\text {ns }}$ \\
\hline Family (F) / S & 192 & $6.49^{\circ}$ & $0.73^{* *}$ & $559.54^{* *}$ & $342.45^{* *}$ & $77.52^{* *}$ & $0.47^{*}$ & $322639.69^{* *}$ & $1024943.10^{\circ *}$ & $4.84^{* *}$ & $71.42^{* *}$ \\
\hline $\mathrm{E} \times \mathrm{F} / \mathrm{S}$ & 192 & $5.38^{\mathrm{ns}}$ & $0.43^{\mathrm{ns}}$ & $229.26^{*}$ & $121.64^{\mathrm{ns}}$ & $19.94^{\mathrm{ns}}$ & $0.47^{*}$ & $111473.85^{\text {ns }}$ & $305887.00^{\mathrm{ns}}$ & $0.98^{\text {ns }}$ & $10.69^{* *}$ \\
\hline Error & 384 & 5.09 & 0.36 & 183.35 & 111.88 & 27.17 & 0.36 & 108603.00 & 295058.50 & 1.06 & 7.79 \\
\hline Mean & & 24.25 & 1.81 & 206.21 & 120.90 & 29.32 & 1.52 & 3178.09 & 2453.95 & 12.11 & 27.69 \\
\hline \multicolumn{12}{|l|}{ Genetic parameters } \\
\hline$\sigma_{g}^{2}$ & - & 0.35 & 0.09 & 94.05 & 57.64 & 12.59 & 0.03 & 53509.17 & 182471.20 & 0.94 & 15.91 \\
\hline$\sigma_{p}^{2^{g}}$ & - & 1.62 & 0.18 & 139.88 & 85.61 & 19.38 & 0.12 & 80659.92 & 256235.80 & 1.21 & 17.85 \\
\hline CVe & - & 4.65 & 16.64 & 3.28 & 4.37 & 8.89 & 19.84 & 11.52 & 11.12 & 4.25 & \\
\hline $\mathrm{CV}_{\mathrm{g}}$ & - & 2.43 & 16.82 & 4.70 & 6.28 & 12.09 & 11.13 & 16.18 & 17.49 & 8.03 & 14.31 \\
\hline $\mathrm{I}_{\mathrm{v}}(\%)$ & - & 0.52 & 1.01 & 1.43 & 1.43 & 1.36 & 0.56 & 1.40 & 1.57 & 1.98 & 2.86 \\
\hline$h_{\overline{X_{f}}}^{2}$ & - & 21.43 & 50.52 & 67.23 & 67.33 & 64.94 & 23.93 & 66.34 & 71.21 & 78.13 & 89.09 \\
\hline
\end{tabular}

$\mathrm{NP}=$ number of plants per plot; $\mathrm{NBP}=$ average number of broken plants; $\mathrm{PH}=$ average plant height; $\mathrm{PHE}=$ average height of the insertion of the first ear; NE = average number of ears; NSE = average number of sick ears; WE = mean weight of ears; GY = grain yield; $\mathrm{W} 100=$ mean weight of 100 grains; PE = popping expansion. $\sigma_{\mathrm{g}}^{2}$ : genotypic variance; $\sigma_{\mathrm{p}}^{2}$ : phenotypic variance; CVe: coefficient of experimental variation; $\mathrm{CV}_{\mathrm{g}}$ : coefficient of genetic variation; $\mathrm{I}_{\mathrm{v}}$ : index of variation, and $h_{\overline{X_{f}}}^{2}$ : heritability on the basis of families. d.f. = degrees of freedom; ns $=$ nonsignificant. $* \mathrm{P} \leq 0.05$. **P $\leq 0.01$.

With regard to genetic parameters, the traits PH, PHE, NE, WE, GY, W100, and PE showed high estimates of genotypic variances and heritability values based on the average of families, over $60 \%$, and an index of variation higher than 1.00 (Table 1). For NP, NBP and NSE, heritability was $21.43,50.52$ and 23.93 , respectively, whereas the rate of variation was $0.52,1.01$ and 0.56 , respectively. The results obtained in this study are consistent with those obtained in previous cycles (Daros et al., 2004; Santos et al., 2007; Freitas Júnior et al., 2009b; Rangel et al., 2011).

The percentage gains predicted by the Mulamba and Mock (1978), for all economic weights, provided positive simultaneous values for the two main traits (GY and PE) (Table 2). Variation index and heritability are economic weights that provided adequate gains for PE (13.34 and 10.12\%, respectively), but these indices indicated smaller gains for GY, 4.05 and $4.25 \%$, respectively. On the other hand, the parameter genetic standard deviation showed satisfactory gains for GY $(22.69 \%)$ and unsatisfactory gains for PE $(2.69 \%)$. In relation to the coefficient index of genetic variation, the gains were adequate for all traits, providing values of 12.11 and $10.57 \%$ for GY and PE, respectively (Table 2).

However, aiming at increasing these two traits and maintaining positive gains for NP, NE and WE and negative gains for NBP, PH, PHE, NSE, and W100, we used the index with weights assigned by attempts close to the values of the coefficient of variation genotype. After 52 attempts, the weights $2.5,17,14,14,10,11,16,35,1$, and 30 for NP, NBP, PH, PHE, NE, NSE, WE, GY, W100, and PE, respectively, provided the best gains for all characteristics (Table 2). These results corroborate those obtained by Santos et al. (2007), Freitas Júnior et al. (2009b) and Amaral Júnior et al. (2010), who assessed the efficiency of the Mulamba and Mock (1978) using weights assigned by attempts.

Figures 1 and 2 contain the boxplots, for a confidence interval of $95 \%$ probability, which represent the variation ranges of 10 traits for the population assessed (200 full-sib families - FIC), the selected population (30 FIC) and the controls. For NP, NE, WE, GY, and PE, selection gains of 0.16 plants/plot, 2.39 ears, $391.31 \mathrm{~kg} / \mathrm{ha}, 380.18 \mathrm{~kg} / \mathrm{ha}$, and $3.06 \mathrm{~mL} / \mathrm{g}$, 


\begin{tabular}{|c|c|c|c|c|c|}
\hline \multirow[t]{2}{*}{ Trait } & \multicolumn{5}{|c|}{ Mulamba and Mock } \\
\hline & SDg & $\mathrm{CVg}$ & Iv & $\mathrm{h}^{2}$ & WAA \\
\hline$\overline{\mathrm{NP}}$ & 0.50 & 0.45 & 0.29 & 0.29 & 0.59 \\
\hline NBP & 2.43 & -7.73 & -4.72 & -6.42 & -5.18 \\
\hline PH & 2.95 & -0.17 & -2.48 & -2.75 & -0.29 \\
\hline PHE & 3.20 & -0.96 & -3.43 & -4.63 & -0.67 \\
\hline $\mathrm{NE}$ & 9.43 & 3.13 & 1.55 & 0.85 & 8.59 \\
\hline NSE & -0.10 & -2.45 & -1.48 & -1.29 & -1.49 \\
\hline WE & 20.58 & 10.28 & 2.18 & 2.29 & 12.84 \\
\hline GY & 22.69 & 12.11 & 4.05 & 4.24 & 15.30 \\
\hline W100 & 3.76 & -0.75 & -4.48 & -4.16 & -0.73 \\
\hline $\mathrm{PE}$ & 2.69 & 10.57 & 13.34 & 10.12 & 10.97 \\
\hline
\end{tabular}

Economic weights used for the selection index: $\mathrm{SDg}=$ genotypic standard deviation; $\mathrm{CV}_{\mathrm{g}}=$ coefficient of genetic variation; $I_{v}=$ index of variation; $h^{2}=$ heritability on the basis of families, and WAA = weights assigned by attempts $(2.5,17,14,14,10,11,16,35,1$, and 30 for each trait, respectively). $\mathrm{NP}=$ number of plants per plot; $\mathrm{NBP}=$ average number of broken plants; $\mathrm{PH}=$ average plant height; $\mathrm{PHE}=$ average height of the insertion of the first ear; $\mathrm{NE}=$ average number of ears; NSE = average number of sick ears; WE = mean weight of ears; GY = grain yield; W100 $=$ mean weight of 100 grains, and $\mathrm{PE}=$ popping expansion.
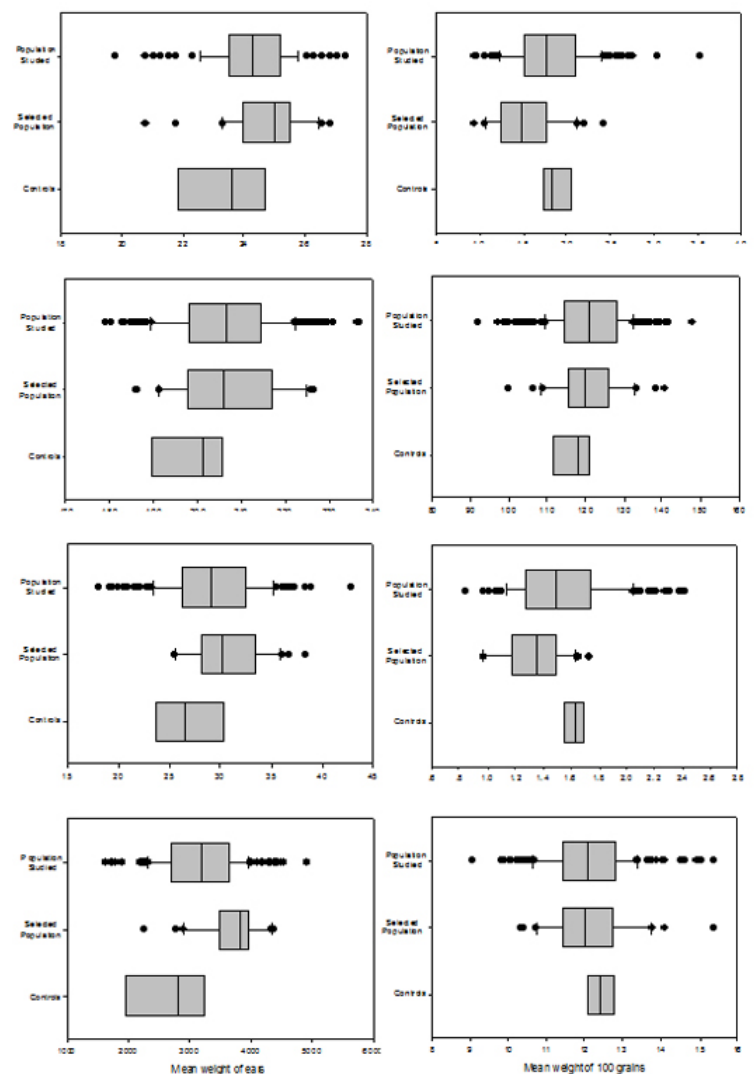

Figure 1. Boxplot for the traits average number of plants per plot, mean number of broken plants, average plant height, ear average height, average number of ears per plot, average number of sick ears, mean weight of ears, and mean weight of 100 grains, in the original population, in the selected population and in the controls. 

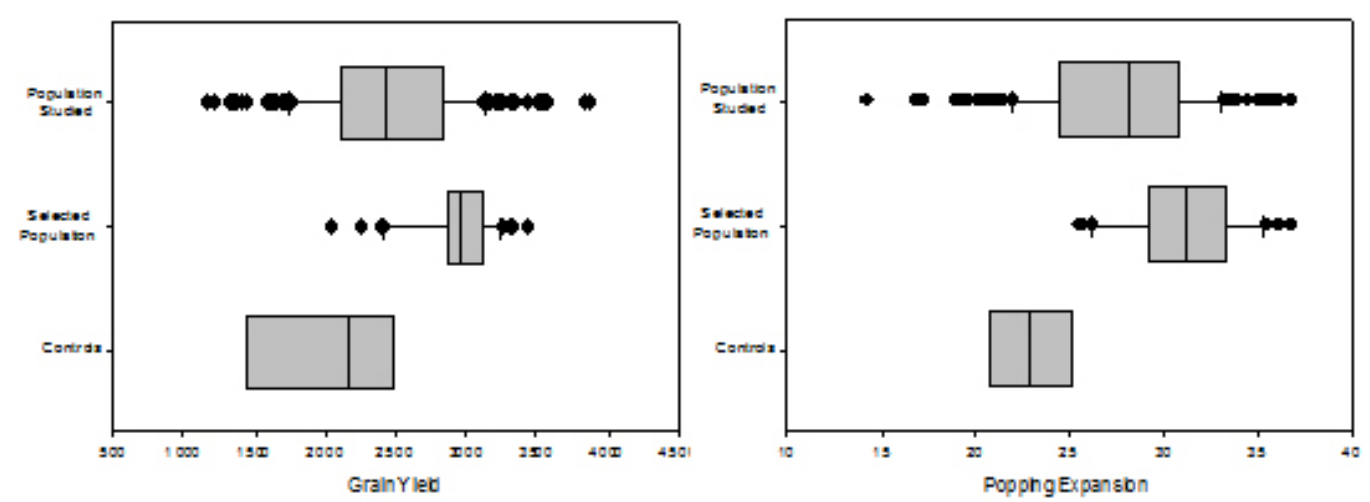

Figure 2. Boxplot for the traits grain yield and popping expansion, in this population, in the population selected and in the controls.

respectively, were expected, whereas for NBP, PH, PHE, NSE, and W100, the following gains were achieved: -0.44 plants/plot, $-0.60 \mathrm{~cm},-0.83 \mathrm{~cm},-0.10$, and $-0.09 \mathrm{~g}$, respectively.

The comparison of the evolution of the means obtained for PE and GY in the $\mathrm{C}_{0}, \mathrm{C}_{1}$, $\mathrm{C}_{2}, \mathrm{C}_{3}, \mathrm{C}_{4}, \mathrm{C}_{5}$ cycles, and those predicted for $\mathrm{C}_{6}$ reveals a steady increase for both $\mathrm{PE}$ and $\mathrm{GY}$, where there was an increase of $1.71 \mathrm{~mL} / \mathrm{g}\left(\mathrm{R}^{2}=0.93\right)$ and $192.87 \mathrm{~kg} / \mathrm{ha}\left(\mathrm{R}^{2}=0.88\right)$, respectively, in each cycle (Figure 3 ). For PE, the base population $\left(\mathrm{C}_{0}\right)$ showed values of 19.89 $\mathrm{mL} / \mathrm{g}$ and reached a magnitude of $31.13 \mathrm{~mL} / \mathrm{g}$, in $\mathrm{C}_{6}$. In other words, there was an increase of
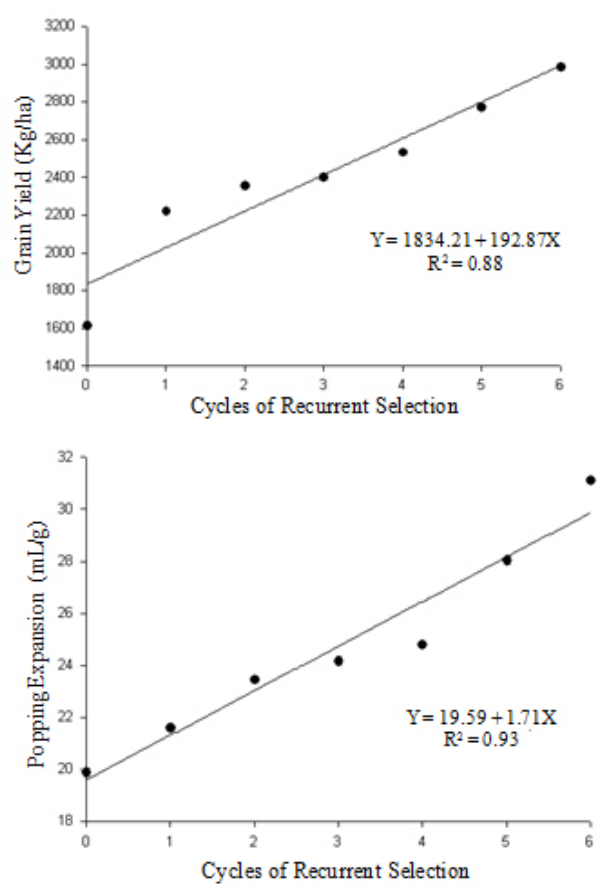

Figure 3. Evolution of the means obtained in the cycles $\mathrm{C}_{0}, \mathrm{C}_{1}, \mathrm{C}_{2}, \mathrm{C}_{3}, \mathrm{C}_{4}, \mathrm{C}_{5}$, and predicted in $\mathrm{C}_{6}$ for the traits grain yield $(\mathrm{kg} / \mathrm{ha})$ and expansion capacity $(\mathrm{g} / \mathrm{mL})$. 
$56.51 \%$ for the expansion capacity in six recurrent selection cycles, corroborating the premise of gradual increase in the frequency of favorable alleles in this population. Similarly, for GY, there was an increase of $85.00 \%$ from $\mathrm{C}_{0}$ to $\mathrm{C}_{6}$ (from 1,615.00 to 2,987.84 kg/ha) (Figure 3). Freitas Júnior et al. (2009a) evaluated the genetic progress of the same population between $\mathrm{C}_{0}$ and $\mathrm{C}_{4}$ and observed increases of $47.00 \%(19.00$ to $28.00 \mathrm{~mL} / \mathrm{g})$ and $63.00 \%(1,700$ to $2,772.00 \mathrm{~kg} / \mathrm{ha}$ ) for PE and GY, respectively.

Therefore, it is possible to conclude that good results were obtained for PE and GY, due to the good performance of the population in the successive cycles of intrapopulation recurrent selection. UENF is expected to provide, as soon as possible, a productive variety with high expansion capacity for producers in the north and northwest of the State of Rio de Janeiro, Brazil.

\section{REFERENCES}

Aguiar CG, Schuster I, Amaral AT Jr, Scapim CA, et al. (2008). Heterotic groups in tropical maize germplasm by test crosses and simple sequence repeat markers. Genet. Mol. Res. 7: 1233-1244.

Amaral Junior AT, Freitas Junior SP, Rangel RM, Pena GF, et al. (2010). Improvement of a popcorn population using selection indexes from a fourth cycle of recurrent selection program carried out in two different environments. Genet. Mol. Res. 9: 340-347.

Cruz JC, Pereira Filho IA and Silva GH (2011). 362 Cultivares de Milho Convencionais e 136 Transgênicas são Disponibilizadas no Mercado de Sementes do Brasil para a Safra 2010/2011. Available at [http://www.cnpms. embrapa.br/milho/cultivares/index.php]. Accessed April 15, 2011.

Daros M, Amaral AT Jr, Pereira MG, Santos FS, et al. (2004). Correlações entre caracteres agronômicos em dois ciclos de seleção recorrente em milho-pipoca. Cienc. Rural 34: 1389-1394.

Freitas Júnior SP, Amaral AT Jr, Pereira MG, Cruz CD, et al. (2006). Capacidade combinatória em milho pipoca por meio de dialelo circulante. Pesq. Agropec. Bras. 41: 1599-1607.

Freitas Júnior SP, Amaral AT Jr, Rangel RM and Viana AP (2009a). Genetic gains in popcorn by full-sib recurrent selection. Crop Breed. Appl. Biotechnol. 9: 1-7.

Freitas Júnior SP, Amaral AT Jr, Rangel RM and Viana AP (2009b). Predição de ganhos genéticos na população de milho pipoca UNB-2U sob seleção recorrente utilizando-se diferentes índices de seleção. Semina 30: 803-814.

Mendes de Paula TO, Gonçalves LSA, Amaral AT Jr, Oliveira EC, et al. (2010). Magnitude of the genetic base of commercial popcorn and in recommendation in Brazil. Crop Breed. Appl. Biotechnol. 10: 289-297.

Miranda GV, Coimbra RR, Godoy CL, Souza LV, et al. (2003). Potencial de melhoramento e divergência genética de cultivares de milho pipoca. Pesq. Agropec. Bras. 38: 681-688.

Moterle LM, Lucca e Braccini A, Scapim CA, Pinto RJB, et al. (2011). Combining ability of popcorn lines for seed quality and agronomic traits. Euphytica. DOI [10.1007/s10681-011-0458-2].

Mulamba NN and Mock JJ (1978). Improvement of yield potential of the Eto Blanco maize (Zea mays L.) population by breeding for plant traits. Egypt. J. Gen. Cytol. Alexandria 7: 40-51.

Pereira MG and Amaral AT Jr (2001). Estimation of genetic components in popcorn based on the nested design. Crop Breed. Appl. Biotechnol. 1: 3-10.

Rangel RM, Amaral AT Jr, Scapim CA, Freitas SP Jr, et al. (2008). Genetic parameters in parents and hybrids of circulant diallel in popcorn. Genet. Mol. Res. 7: 1020-1030.

Rangel RM, Amaral AT Jr, Gonçalves LSA, Freitas SP Jr, et al. (2011). Análise biométrica de ganhos por seleção em população de milho pipoca de quinto ciclo de seleção recorrente. Rev. Cienc. Agron. 42: 473-481.

Santos FS, Amaral AT Jr, Freitas SP Jr, Rangel RM, et al. (2007). Predição de ganhos genéticos por índices de seleção na população de milho pipoca UNB-2U sob seleção recorrente. Bragantia 66: 389-396.

Sawazaki E (2001). A cultura do milho pipoca no Brasil. Agronômico 53: 11-13.

Silva VQR, Amaral AT Jr, Scapim CA, Freitas SP Jr, et al. (2010). Inheritance for Economically Important Traits in Popcorn from Distinct Heterotic Groups by Hayman's Diallel. Cereal Res. Commun. 38: 272-284.

Silva VQR, Amaral AT Jr, Gonçalves LSA, Freitas SP Jr, et al. (2011). Heterotic parameterizations of crosses between tropical and temperate lines of popcorn. Acta Sci. Agron. 33: 243-249.

Simon GA, Scapim CA, Pacheco CAP, Pinto RJB, et al. (2004). Depressão por endogamia em populações de milhopipoca. Bragantia 63: 55-62. 